InOedia $\quad \begin{aligned} & \text { InMedia } \\ & \text { The French Journal of Media Studies }\end{aligned}$

8.2. 2020

What do Pictures Do? (In)visibilizing the Subaltern

\title{
Public Violence: Viral Images Give the Alert
}

\section{André Gunthert}

Translator. Robert Jones

\section{CpenEdition}

\section{Journals}

\section{Electronic version}

URL: https://journals.openedition.org/inmedia/2660

DOI: 10.4000/inmedia.2660

ISSN: 2259-4728

\section{Publisher}

Center for Research on the English-Speaking World (CREW)

\section{Electronic reference}

André Gunthert, "Public Violence: Viral Images Give the Alert", InMedia [Online], 8.2. I 2020, Online since 22 October 2021, connection on 28 October 2021. URL: http://journals.openedition.org/inmedia/2660 ; DOI: https://doi.org/10.4000/inmedia.2660

This text was automatically generated on 28 October 2021

(C) InMedia 


\title{
Public Violence: Viral Images Give the Alert
}

\author{
André Gunthert
}

Translation : Robert Jones

\section{Introduction}

1 Since the revolutions of the Arab Spring in 2011, the idea has taken hold that digital technologies-smartphones and social media-could be used to spread the message and the imagery of protest movements autonomously, and that activist communication could make up for the inadequacies of media coverage. ${ }^{1}$ In France, the 2018-2019 gilets jaunes (yellow vests) crisis appeared to corroborate this theory. In 2020, the documentary The Monopoly of Violence (Un pays qui se tient sage), directed by the independent journalist David Dufresne, compiled and commented on fifty-five videos recorded during demonstrations by participants, witnesses or professional video journalists. ${ }^{2}$ The clips are presented as direct testimonies though there is no indication of where the footage came from nor of how it was virally selected. To the watching public most of the clips are recognizable: they were shared across social media and often picked up by television news, becoming some of the most discussed images of the crisis.

2 The issue of the access of subalterns ${ }^{3}$ or counter-publics ${ }^{4}$ to recognition in unequal societies is one of the great questions of the social sciences. Do these new types of images, by virtue of their autonomous production and distribution, provide a privileged pathway to this recognition? According to Alain Bertho, "The production and sharing of images becomes a central element of the contemporary repertoire of protest and of the production of the collective, in the same way as the leaflet, the banner, the slogan or the general assembly in the modern repertoire." This selfmediation is not limited to communication objectives; "It becomes a moment of the production of statements and the production of the collective." ${ }^{5}$ 
If the gilets jaunes crisis again sparked this self-mediation, it also gave rise to another form of exploitation of the digital mediation. On social media, part of the audience participated in the construction of the narrative by appropriating the audiovisual documents, sharing or redocumentarizing them through commentary. Internet users did amplify the visibility of the images and eventually helped the emergence of the theme of police violence. This process has its own mechanisms, based on the alert function, the narrative interpretation of video documents and their viral diffusion. These factors have contributed to making the viral images a powerful counternarrative against illiberal drifts of French democracy.

\section{From sousveillance to raising the alert}

Released in 2019, Ladj Ly's film Les Misérables was inspired by events in 2015, when, following a spate of terrorist attacks, the French government declared a state of emergency granting extensive police powers. ${ }^{6}$ Focusing on the heated relations between a team from the French anti-crime brigade (BAC) and the residents of the Bosquets housing project in Montfermeil, the film includes several pieces of footage showing police actions from the locals' point of view, in the context described by Steve Mann as sousveillance, or reverse surveillance, whereby citizens use digital technology against the police. ${ }^{7}$

In the first example, a young girl holds up her cell phone while police stop and search her friend. She hardly has time to turn it on before the police officer in question throws it to the ground and breaks it. The final third of the film depicts the brigade's attempts to destroy evidence by retrieving a drone that has filmed officers making an arrest, during which a shot from a 'flash-ball' riot gun hit a young boy in the face.

Sousveillance practices took hold in the United States of America in the early 1990s in the form of copwatching, whereby police abuses, brutality or extortion during arrests or crowd control operations in public areas were not only recorded but also shared publicly. The video of George Holliday beating Rodney King on March 3, 1991, broadcast on a loop the following day as "Breaking News" on CNN, was followed in April 1992 by a week of riots in Los Angeles after the acquittal of the accused officers, thereby demonstrating the social power of making police violence a concrete reality. The use of copwatching in a work of fiction underlines how widespread the practice has become. In order to portray typical aspects of daily life in these neighborhoods, Ladj Ly not only shows reverse surveillance to be a reflex reaction of minorities in the face of police harassment but also uses it as a major dramatic element in a narrative of confrontation with the police.

7 In this context, what is striking is the essentially symbolic character of the use of sousveillance. The young girl whose telephone is broken does not film anything, and while video takes on an allegorical dimension in the shape of the drone, an all-seeing eye that flies over the city, the film of the arrest, which is barely shown on screen, is eventually recovered and destroyed by the police (fig. 1). The recordings are never shared online and only ever represent a virtual threat. 


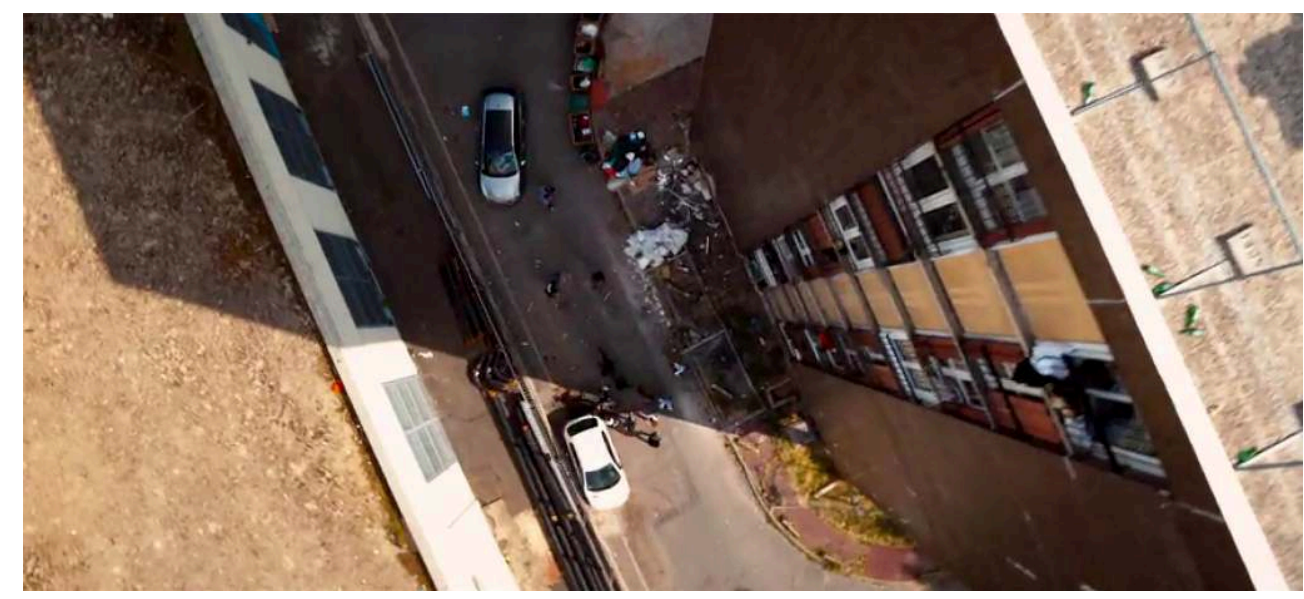

Fig. 1: Les Misérables, the scene of the arrest as seen by the drone (still frame).

8 The characters in the story are united in their belief in the power of these images. The residents film, and the police fear being filmed, underlining a founding principle of sousveillance: in the context of a power asymmetry, images are supposed to redress the balance of power in favor of ordinary citizens. ${ }^{8}$ Yet in Les Misérables this remains theoretical. The threat of power being rebalanced moves the plot forward but has no real consequence for the perpetrators of the violence.

9 This mythological role of video in Les Misérables illustrates a stereotypical view of the medium as evidence, which is inherent to the narrative of sousveillance. Admittedly, in the case of police violence, where officers usually seek to cover up their actions, the existence of evidence, a surveillance video or a smartphone recording, can decisively alter an investigation. ${ }^{9} \mathrm{However}$, despite the thousands of documents released in the context of the gilets jaunes movement, very few police officers have been prosecuted. In June 2020, out of the 378 investigations relating to accusations of violence entrusted to the General Inspectorate of the National Police (IGPN), only two cases resulted in sanctions. ${ }^{10}$

10 In order to move beyond the merely technical dimension of sousveillance and analyze the social impact of videos, it is necessary to consider the social alert process, as described by Francis Chateauraynaud. ${ }^{11}$ Indeed, the alert constitutes a parallel communication system that is activated under and determined by a specific set of conditions. First and foremost, it intervenes in a deficient system whose corrective mechanisms have proven to be incapable of remedying its shortcomings. The primary objective of an alert is to expose publicly information that is kept hidden, in order to generate external pressure to right a wrong. The existence of a risk or danger to the community confers a strong moral legitimacy on the action undertaken, regardless of the possible irregularity of the means employed.

11 Alerts are distinct from both journalistic coverage and activist communication. Indeed, alerts and news media draw their credibility from contradictory sources. The value of an alert comes not from a neutral observation which establishes the objectivity of the message, but rather from the source's very role of participant on the ground. Without the guarantee of a media brand, those raising an alert must provide indisputable evidence to back up their reports. Information is made freely available to maximize its dissemination. 


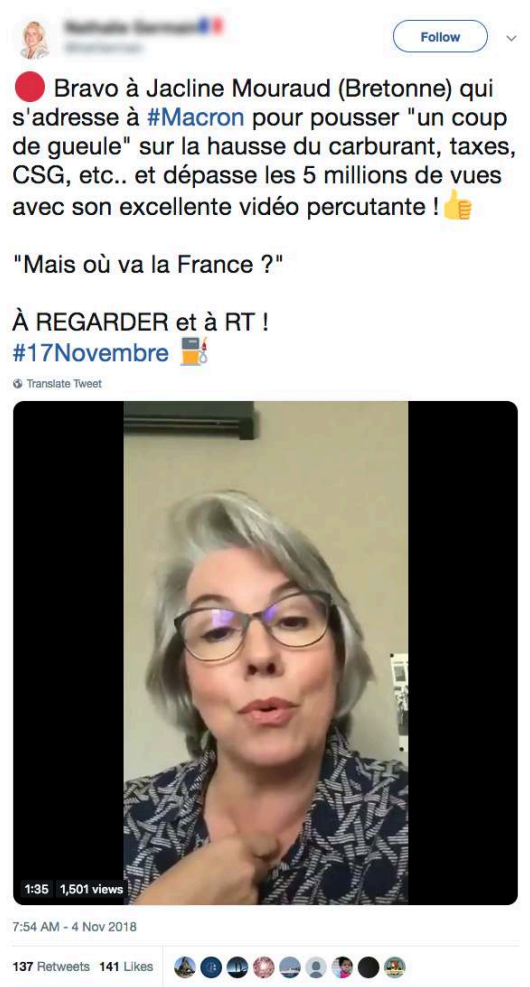

Fig. 2: A Twitter post sharing Jacline Mouraud's video, November 4, 2018 (screenshot).

The text of the tweet reads: "Well done Jacline Mouraud (from Brittany) who has "a rant" at \#Macron about rising fuel prices, taxes, social security contributions, etc. and has had more than 5 million views with her brilliant hard-hitting video. "What is France coming to?" WATCH and RT! \#17November"

This becomes evident in the ways in which images are circulating online. By allowing the public to produce and publish messages, the internet is evidently conducive to the alert process. Moreover, its mythology upholds the idea of direct communication with even the most inaccessible public figures. The video addressed "to Mr Macron and his government" by Jacline Mouraud, published on October 18, 2018, became the first viral hit of the gilets jaunes movement, precisely because it took that direct message character..$^{12}$ In showing the protest of a bluntly outspoken, anonymous woman who looks her government in the eye, the video was the embodiment of the face-to-face encounter that the gilets jaunes sought (fig. 2). Similarly, the journalist David Dufresne's Twitter compilation of testimonies by injured demonstrators is entitled "Allo place Beauvau-c'est pour un signalement" ("Hello, place Beauvau-I'd like to make a report"), which by metonymy points the finger at France's Ministry of the Interior publicly implicating those responsible for law enforcement.

Beginning on December 4, 2018, David Dufresne's series of reports systematically records images documenting violence, ${ }^{13}$ most often in the form of photographs or videos posted on social media by the victims themselves or by direct witnesses (fig. 3). In the alert process, the recorded image constitutes the evidence that triggers the report. The use of images changes the nature of the message, transforming the expression of a personal opinion into a vector of objective information.

14 Audiovisual recordings enjoy a strong a priori assumption of authenticity, provided that they have not been altered or decontextualized, and that there is sufficient information for the events depicted to be identified. However, since 2016, social networks have 
attracted suspicion because of the large amount of fake news that they spread, and most internet users cannot easily determine the accuracy of a message ${ }^{14}$ It is for this reason that David Dufresne, applying journalistic standards to his sources, sets himself the task of verifying the evidence that he shares, thus reinforcing its value.

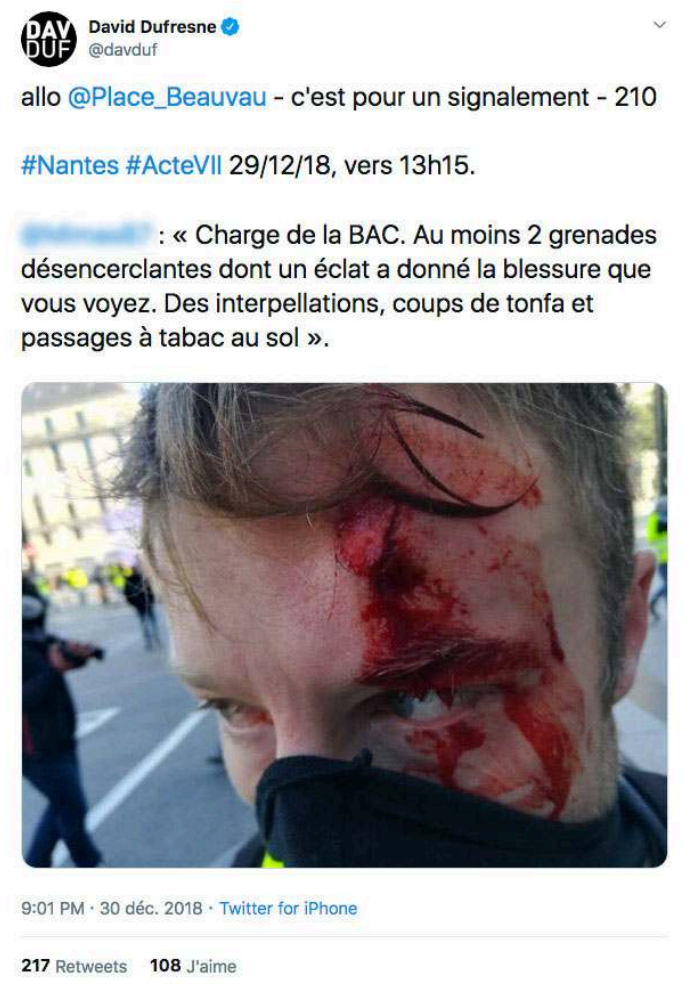

Fig. 3: David Dufresne, Twitter post, December 30, 2018 (screenshot).

The text of the tweet reads: "Charge by the anti-crime brigade. At least two sting ball grenades, one of which caused the injury you can see below. Arrests, blows from batons and beatings on the ground."

Yet despite its major role from the beginning of 2019, Dufresne's compilation was not the most successful viral material in December 2018-January 2019. Very often the most shared content, retweeted with or without commentary, comes directly from those on the ground. The credibility of such material is deduced pragmatically using a set of contextual criteria. Signs of proximity to the events, rather than an identifying byline, act as a guarantee. The speed with which the document is put online, while an event is still underway or shortly after it has finished, provides a first clue. The next major step is the analysis of footage, which situates the source within events and testifies to his or her participation in them. Finally, content is subjected to test by debate: in a context of polemical exchange, messages are scrutinized by both sides in a process that quickly weeds out the most disputable content. In a short space of time, content that has stood up to criticism from internet users who were closest to the events will be considered as de facto validated.

The online circulation of the material offers a crucial indication of its validation. Since social networks make it possible to identify who has posted content and to track repeated mentions of a source, the level of a message's virality can be gauged by the number of different users sharing it and the accelerating rate at which it is reposted. The term virality refers not to a medium but to a state of the medium: the increased 
circulation of content resulting from a rapidly growing participatory selection process. Internet users know a message is viral when it is repeated by a number of different users in a short space of time. As the algorithm increases circulation in proportion to the number of interactions generated (likes, reposts, comments), content can quickly reach a large number of views-from a few thousands to several million in the most successful cases.

Minority groups use virality to gain exposure on a level with major media outlets. Whereas content on mainstream platforms is accessed passively, social media allows internet users to express their individual interest in material, which can be used as a tool to draw greater attention to a cause. This process is now among the phenomena commonly examined by the press during discussions about current affairs. Virality thus grants the anonymous a voice and access to greater media coverage. Although supporting a cause online ("slacktivism") is often considered a small gesture, particularly when compared to activist involvement, ${ }^{15}$ the increased circulation that results from viral selection is perfectly aligned with the objectives of the alert, which aims to mobilize public opinion in order to force those in positions of power to answer for their actions.

The primacy of the actor over the mediator, direct access to the source, the receiver who takes on the task of remediation: the internet fosters the conditions of what Jay David Bolter and Richard Grusin call immediacy-direct communication devoid of intermediation. ${ }^{16}$ This is not necessarily considered an asset. During the selfie crisis of 2014, the self-referential dimension of the genre led to a critique of narcissism. But when a message is identified as an alert, the perception is different because the message is disinterested and of value to the community. The markers of immediacy then function as the equivalent of signs of authenticity. From this perspective, the formal imperfections inherent to an improvised shot, such as a shaky or poorly framed image, are not considered as defects but as confirmation that the material has the invaluable quality of being directly from the ground.

The strength of this alternative format and the credibility it enjoys are reflected by the fact that, as early as December 2018, some of the newer press agencies involved in covering the gilets jaunes movement abandoned the traditional distribution channels for marketing audiovisual productions, choosing to share raw footage freely on social networks that uses the formal vocabulary of amateur videos: short unedited clips with live audio. David Dufresne has adopted a similar approach with his public documentation of police violence on Twitter. By playing the game of viral circulation and accepting the constraints of unfiltered presentation, these journalists bear witness to the shift in a landscape where alerts have supplanted mediation.

\section{From alert to counter-narrative}

Broadcast live on Facebook on May 25, 2020, the video of the murder of George Floyd by police officers in Minneapolis met with an overwhelming emotional response, as several months of demonstrations, riots and debates over racist violence, in the USA and around the world, followed. But the spectacle of a black man in excruciating agony also provoked a moral critique of the use of images. In a New York Times article entitled "Please Stop Showing the Video of George Floyd's Death" published on June 4, Melanye Price, a professor of political science, deplored the news channels and internet users 
endlessly showing brutal images which called to mind the public lynching of black people in the USA. ${ }^{17}$ The debate that accompanies these episodes is indicative of the discomfort and contradictions caused by the exhibition of suffering. ${ }^{18}$

Price recalls that following the September 11 attacks or the beheading of hostages by jihadists, the American media independently chose to moderate or limit the depiction of violent acts, both to spare the public and out of respect for the victims. She points out that the same precautions do not seem to be taken with the death of a black person, and fears that such images may fuel stereotypes about specific forms of violence being inherent to black history. She also notes that the repeated use of such footage does not seem to change police culture or improve the safety of minorities in public spaces. Without questioning the need to denounce racist crimes, she calls for rules of moderation and self-censorship in line with the way violent acts are generally covered.

Although well-intentioned, such a request is nonetheless paradoxical. Indeed, the representation of violence in mass media is generally handled euphemistically. ${ }^{19}$ Using violence in alerts creates a deliberate contrast with this moderating process, which in itself suggests a difference in nature between the forms of communication, and a shift to a regime of truth based on the revelation of hidden facts. The exposure of violence is not only the objective presentation of the events to be denounced: it is constitutive of the alert, through the change of regime and the urgency it imposes, through the increased attention it raises, and because exceptional brutality signals a dysfunction whose causes need to be examined. With most image-based alerts, such as the videos of the animal rights group L214 or copwatching, the exposure of violence constitutes the primary component of the process. ${ }^{20}$ It must be understood as a weapon in the service of the alert, the catalyst that establishes the need to sound the alarm and defines the framework in which it is to be read, the proof of the gravity of a problem, and a tool for raising public awareness and winning public support.
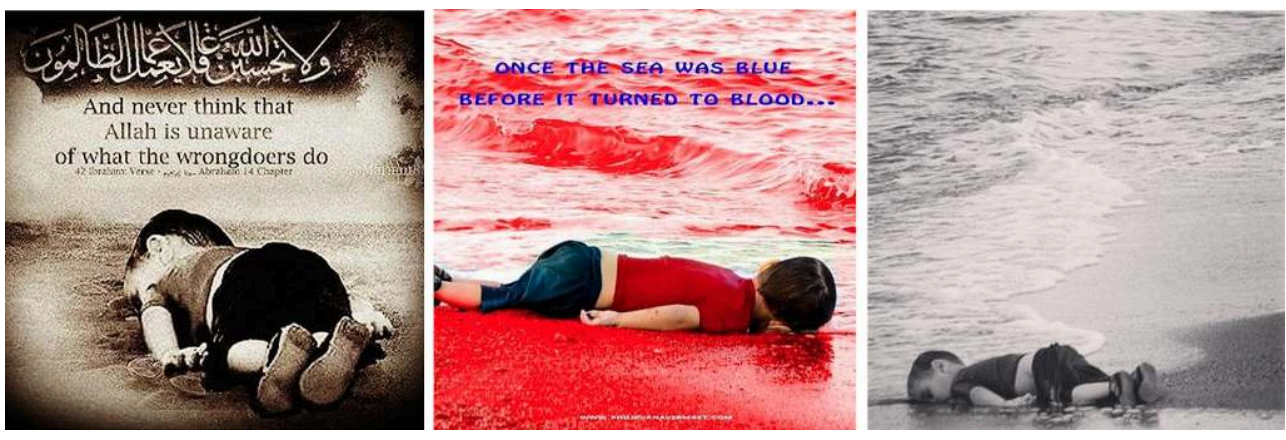

Fig. 4: Remediation of photographs of Aylan photos on Instagram, 2015 (screenshots).

Yet in reality there always remains a disconnect between the facts and their representation. The clearest example of this can be seen in the iconography of little Aylan (Alan), a Syrian refugee who drowned on a beach in Turkey in September 2015 and whose image acted as an alert in the crisis of the European policy of refusing to accept migrants (fig. 4). The sight of the corpse of an innocent child provoked an intense emotional response-but the media could use the image only because the toddler's face, half-buried in the sand, was hidden. Alan had a brother, Galip, who died in the same circumstances, but his image was not shared because the dead child's visible face is unbearable to behold. Similarly, the most shocking images of the wounds suffered by the gilets jaunes, such as those who lost an eye or had a hand torn off, did 
not go viral. On the contrary, it was often the most trivial acts that were most widely shared. Footage of a policeman maliciously tripping a protestor and causing her to fall to the ground in January 2020 in Toulouse (fig. 5) was shown onscreen during France 2's television news show to challenge Prime Minister Édouard Philippe on the issue of police violence. ${ }^{21}$

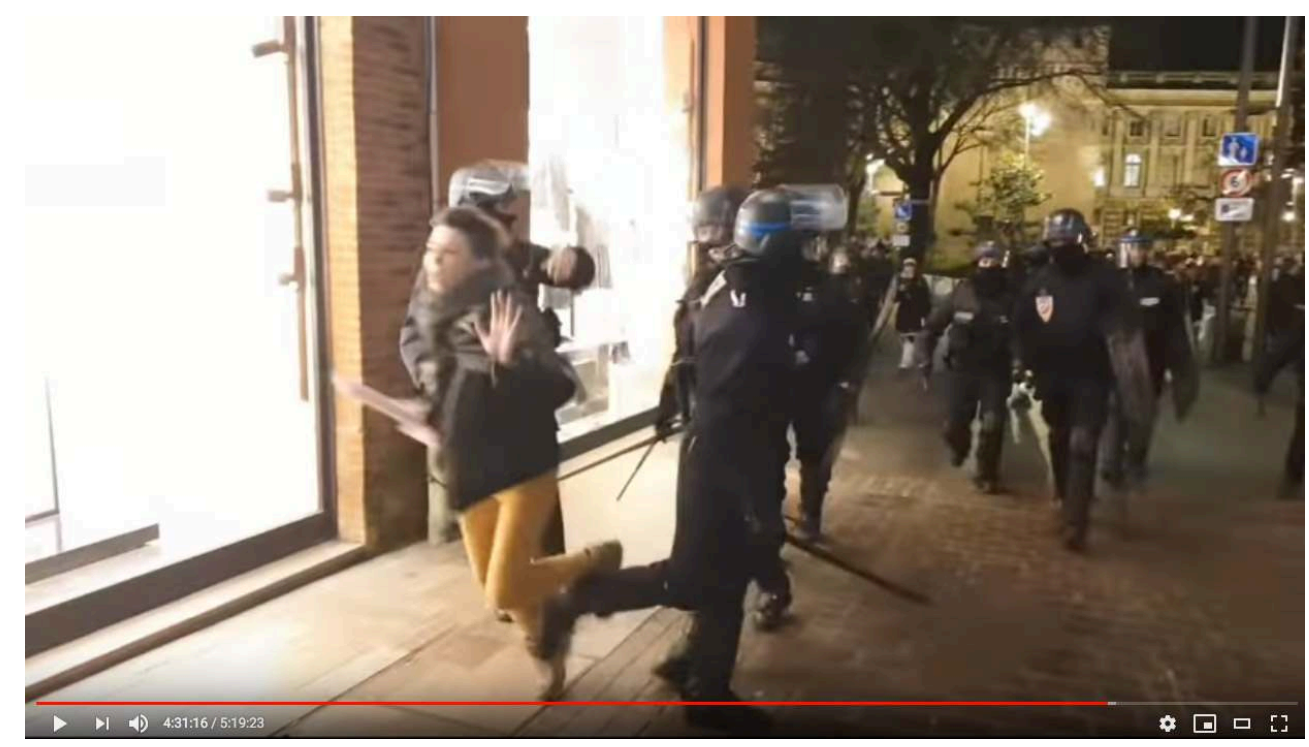

Fig. 5: Djemadine, a policeman trips a demonstrator, Toulouse, January 9, 2020 (still frame).

Though deployed in the alert process, the exposure of violence is nonetheless carefully measured and controlled, and more particularly narrativized. The debates around videos like the Toulouse clip do not so much seek to determine whether or not a violent act has occurred, but rather examine the justification for the act or the role of its perpetrator. Although the police officer's action is insignificant on the spectrum of brutality, the clip exposes a malevolent and unjust act that in no way serves to maintain order. Police violence is thus far from an objective phenomenon that can be easily identified simply by examining images. On the contrary, images are interpreted through a filter of contradictory rationalizations which can completely change the ways in which they are read, in at least three respects.

While the very expression "police violence" suggests a systemic problem, authorities consistently respond by describing the alleged incidents as isolated acts, excesses that will be investigated. Testimony can also be countered by legitimizing brutal acts as a "proportionate response", necessary to maintain order. Online discussions about videos of misconduct often call for the action depicted to be "contextualized" within a broader sequence of events in order to give them a new interpretation. Finally, there is a wide, though largely unspoken, gulf in the perception of policing, which a survey published in January 2020 showed to be largely correlated with political opinions: while $68 \%$ of those on the right and supporters of President Macron's party believed that law enforcement had not used excessive force, $62 \%$ of those on the left believed the opposite. ${ }^{22}$ The sample population is thus split into two roughly equal parts. Presented with the same images, people can therefore have conflicting views either on how the violence should be interpreted or on the very necessity of using force.

These unstable interpretative frameworks were evident in the case of footage filmed in Mantes-la-Jolie in December 2018, at the beginning of the gilets jaunes crisis, showing 
police detaining 150 high-school students forced to kneel with their hands on their heads (Fig. 6). One officer filmed the scene and shared it on social media as a trophy celebrating the victory of the rule of law. The emotional reaction to the video contradicted Melanye Price's view that a display of violence necessarily makes the viewer share the perpetrator's point of view. On the contrary, the humiliation suffered by the students in Mantes-la-Jolie aroused anger and indignation. While these feelings were shared only by more progressive members of the public, such a reception demonstrates that the manner in which images are interpreted is determined not so much by the depiction of the events as by the scenario that the viewer projects onto them. Although it was shared by the perpetrator of the violence, the video from Mantes-La-Jolie was read mostly as an alert and a denunciation of misconduct.

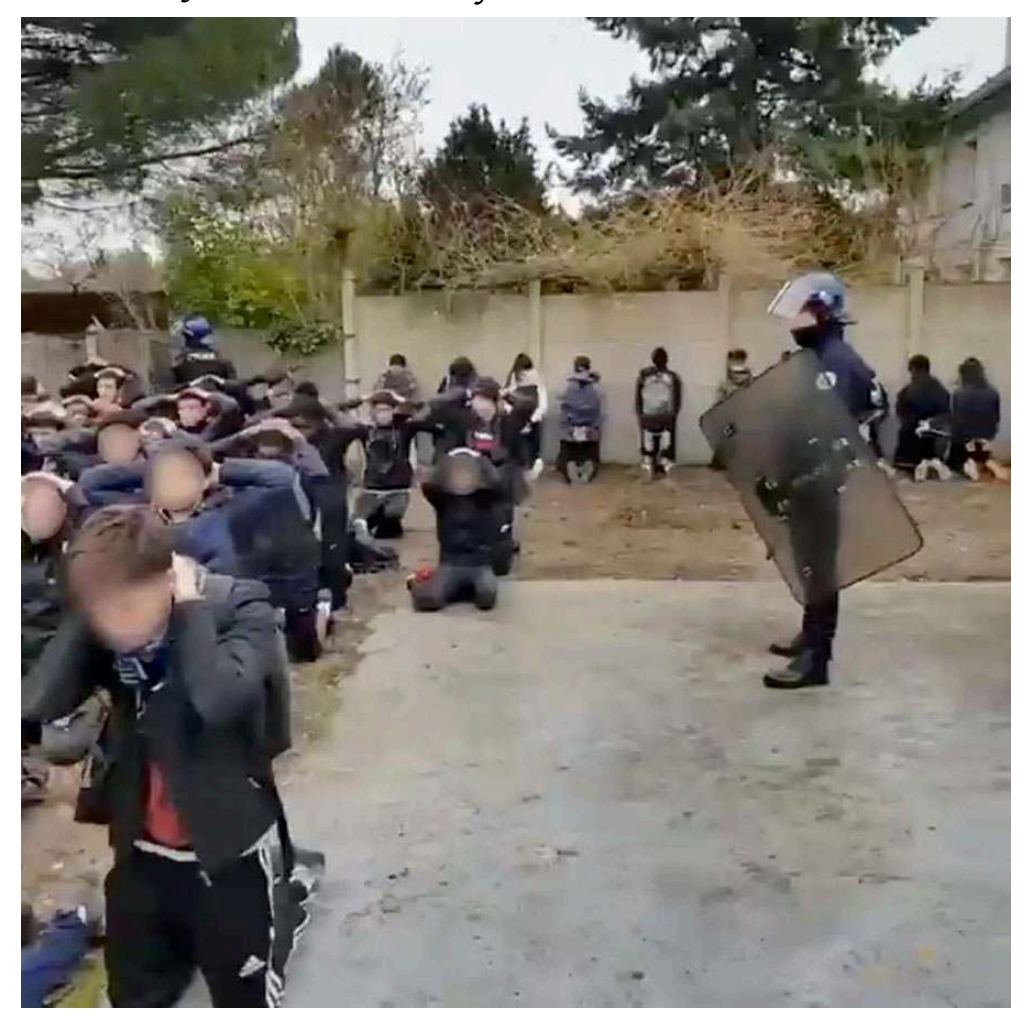

Fig. 6: Anonymous, arrest of high school students, Mantes-la-Jolie, December 6, 2018 (still frame).

The Mantes-la-Jolie episode serves to underline that the signs of conflict are interpreted independently upon reception by the viewer. Autonomous readings of the movement were encouraged by both the gilets jaunes movement's refusal to designate spokespersons and the mainstream media's difficulty in conveying what was happening on the ground. The theme of police violence, which appeared as early as December 2018 in radical left-wing media, did not cross over from activist communication, largely unnoticed by the general public. Rather, the issue came to the fore chiefly because each demonstration brought evidence of the excessive use of force, namely in the aggressive use of blast balls, and repeated images of wounded people. The evidence of such violence itself created a de facto alert process, which gradually came to be superimposed on the political and social demands of the gilets jaunes.

The Monopoly of Violence is in its own way a testament to the ways in which videos are received $^{23}$. David Dufresne invites intellectuals, witnesses or participants to react to, 
and sometimes discuss, documentary material, which is often projected in the background. Replaying the footage in this set-up, in order to provide a basis for commentary in the form of public debate, functions as a metaphor for the powerful conversational dynamics that have shaped the narrative of police violence.

Viral images are not so much objective documents as narratives in the making, social constructs forged in real time through discussion on social media. ${ }^{24}$ The lively debate around the footage of Farida's arrest on the evening of June 16, 2020, in Paris lays bare the narrative mechanisms behind the ways in which such material is read. After the first post-lockdown demonstration by healthcare workers there was clear anger in online conversations at the violent repression of the protesters as typically indiscriminate policing served only to stir up tensions. A first recording from the scene, posted on Twitter at 4:58 p.m., catches viewers' attention with the clearly audible cry of a healthcare worker in a white lab coat being manhandled by several police officers: "I want my Ventolin". ${ }^{25}$ This narrative key echoes the terrible plea "I can't breathe" from the footage of George Floyd from a month earlier, linking the videos within the pattern of police violence. The effect is reinforced by other signs, such as the asymmetry of the confrontation between an isolated woman and the indistinct mass of agents crowded around her body.

This distressing image of macho policing was reinforced at 6:32 p.m. by a tweet commenting on the video: "This woman is my mother. 50 years old, a nurse, for 3 months she worked between 12 and 14 hours a day. She's had Covid. Today, she was demonstrating for a pay rise, for her work to be recognized. She is asthmatic. She had her lab coat on. She is 5 foot 1 ". ${ }^{26}$ Identifying the nurse and explaining her peaceful presence there helps to reinforce the storyline. When footage taken from Rémi Buisine's live reporting was shared at 6:52 p.m., giving a clearer version of the altercation, it had already taken on an allegorical value in its portrayal of a symbol of martyrdom, a victim of patently unjust and disproportionate violence by the forces of law and order. ${ }^{27} \mathrm{~A}$ photograph by Antoine Guibert provided an emblematic summary of the scene, gaining further exposure still and giving rise to extensive commentary. ${ }^{28}$

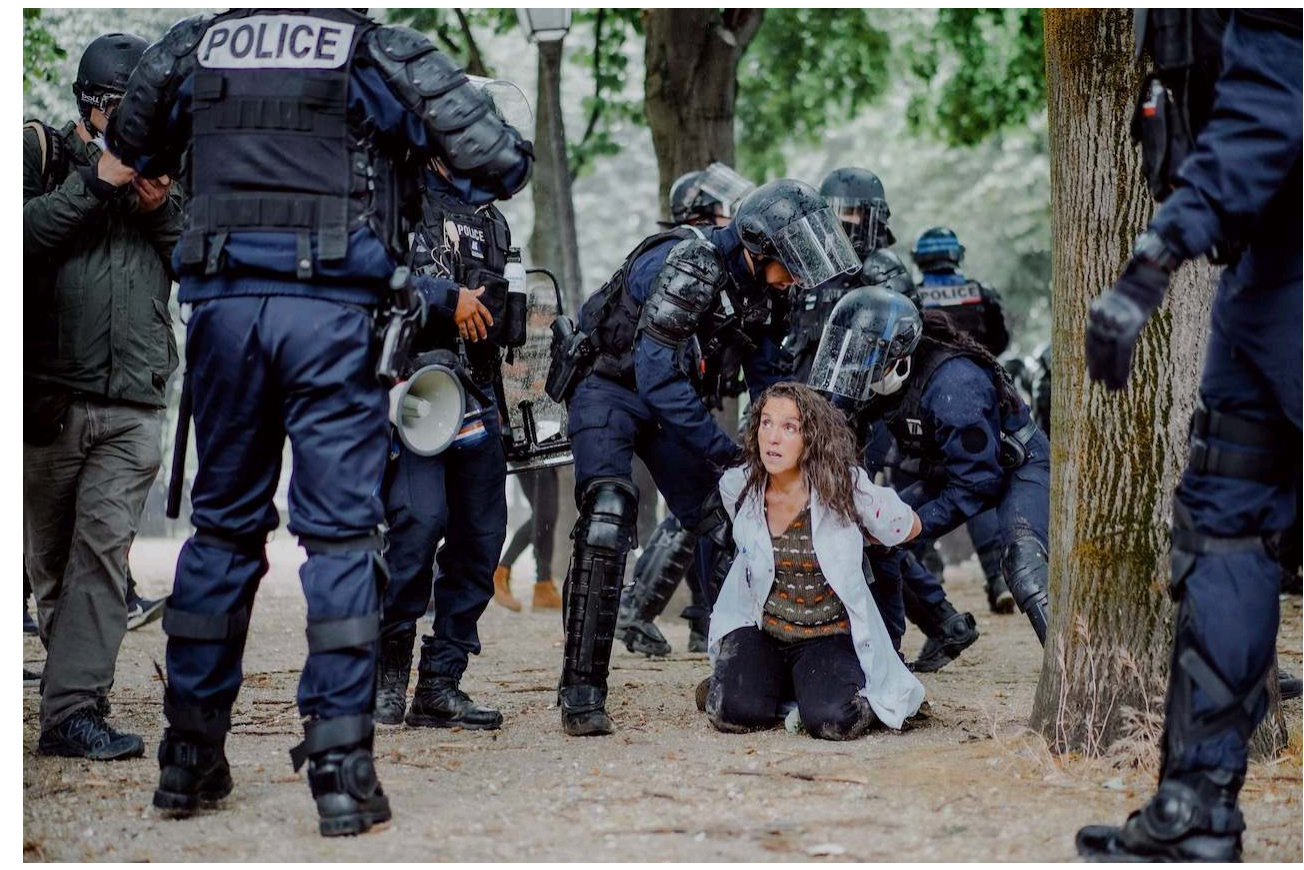


Fig. 7: Antoine Guibert, the arrest of Farida, June 16, 2020.

31 In the words of journalist Daniel Schneidermann, “The revolt of the healthcare workers has found its icon". ${ }^{29}$ But later that evening the police reacted by sharing new footage filmed a few minutes before the arrest showing the nurse raising her middle finger at the police and throwing rubble in their direction..$^{30}$ Denials followed lies as numerous tweets questioned the nurse's status or accused her of political activism. Her brutal arrest was perfectly justified in the eyes of the supporters of repression, who thereby reversed the dominant narrative of the whole gilets jaunes movement. She could not be considered a victim: on the contrary, her actions showed her to be a culprit.

What comes across clearly in this exchange of arguments is how interpreting cues according to pre-established roles leads to a stereotyped reading of the scene. Supporters of the healthcare workers looking for clear evidence of police misconduct settled on a video that brought together all the features of a victim figure, evocative of the aesthetic of pity analyzed by Luc Boltanski. ${ }^{31}$ In the online discussions that act as a selection process, with each side's arguments subject to the reaction of its adversaries, the footage should have been rejected because the fact that the arrest was justified by the nurse's reprehensible acts made it vulnerable to criticism. However, the speed with which supporters rallied around the figure of Farida, and the unique nature of the protest by healthcare workers, who were seen as heroes, set the construction of the narrative on a different course. In an unexpected twist, new arguments were produced in support of Farida, laying out the reasons for the healthcare workers' anger, or emphasizing that the police do not possess punitive powers and that corporal punishment is not part of the arsenal of law enforcement. These arguments met little solid objection. Indeed, in a reversal of the interpretation of the events, Farida was even transformed from victim into heroine.

This allegorization is only possible when footage is very easy to read, when both the action and the motivations of those involved are easy to understand. This is one of the selection criteria for viral videos. A decisive factor is the combination of a short video and a plot offering some sort of closure, which allows the footage to be used as a standalone message, with no need for external reference or additional information-which is crucial if an extract is to be replayed, and thus become viral. As such, in the case of short clips that are not necessarily easy to understand, the possibility offered by online platforms to rewatch the footage at will is crucial, especially when the debate requires the careful examination of details that may alter the viewer's interpretation.

Another aspect of the social construction of the narrative of police violence is the longterm repetition of acts of violence which together form a story. Despite the repeated denials of the highest-ranking officials of state, the mass of evidence that has built up ultimately lays bare the reality of the systemic nature of police brutality. This underlines the value of David Dufresne's work cataloguing this evidence, as he is the only French journalist to have furnished the question of police violence with an historical perspective. His videos and numerous appearances in the public sphere from January 2019 onwards have helped to construct a narrative around police violence, which over the course of the year evolved from an alert to a counter-narrative.

If we consider social narratives as ways of organizing the collective imaginary, the term counter-narrative can be used when a minority idea has become an identifiable motif and part of the conversation in the public sphere. This is indeed the case with the 
theme of police violence, which was largely absent from French public debate before coming to the fore during the gilets jaunes crisis in January 2019. While a poll conducted in 2016 during demonstrations against labor law reforms showed that only $21 \%$ of French people considered the use of force by the police to be excessive, ${ }^{32}$ this figure rose to $45 \%$ in January 2020 (Odoxa). Such widespread condemnation, from nearly half of the population, is unprecedented. A study of the reporting of the gilets jaunes crisis in the mainstream media confirms that the issue went unreported in December 2018, before slowly gaining prominence throughout the whole of 2019. ${ }^{33}$ This therefore constitutes a documented case of a minority opinion being transformed into a majority opinion. The political decision to repress the demonstrations and the unusually longrunning conflict meant that, despite media and political resistance, the question of police violence emerged as a major example of a counter-narrative, resulting from an alert process primarily based on viral images.

The success of the alert depends not only on the mobilization of the public, but also on the response of the authorities. According to the results of this process, Francis Chateauraynaud identifies three types of alerts. ${ }^{34}$ The police violence alert falls into the last category, which marks its failure and the refusal to recognize its validity. The power of denial expressed at the head of the State can be explained both by the long history of the strategic choices of the maintenance of the French order, and by the impossibility in which the order givers found themselves to publicly assume choices that set fundamental freedoms into question. ${ }^{35}$ However, in this specific case, the denial took the paradoxical form of recognition, through the proposed law on Global Security, amended during the month of October 2020 to prohibit the identification of police through online videos. Its article 24 drew unanimous protest from the media world. ${ }^{36}$ On November 5, 2020, the deputy Jean-Michel Fauvergue, elected by the majority and rapporteur of the law, admits before the preparatory commission: "Let us be clear: the authority, the State in particular, is losing the war of images" ${ }^{37}$ Weeks later, the vote of the law at first reading is not the response whistleblowers were hoping for. But it is a way to admit that the agenda setting of police violence by online videos has indeed been taken into account by the authorities.

\section{Conclusion}

In March 2019, the proliferation of images of violence led the social media Facebook to hide photographs or videos identified as suspect behind a warning that requires users to actively choose to access the content. This restriction, which goes against the principle of free publication that has been behind the success of social media, has, as expected, limited the virality of content defined as undesirable. The algorithm is of course incapable of distinguishing between posts that gratuitously display violence and those exposing violence in order to denounce it-because the poster's intention can be understood only with the help of information that provides context, and not through the image itself. 


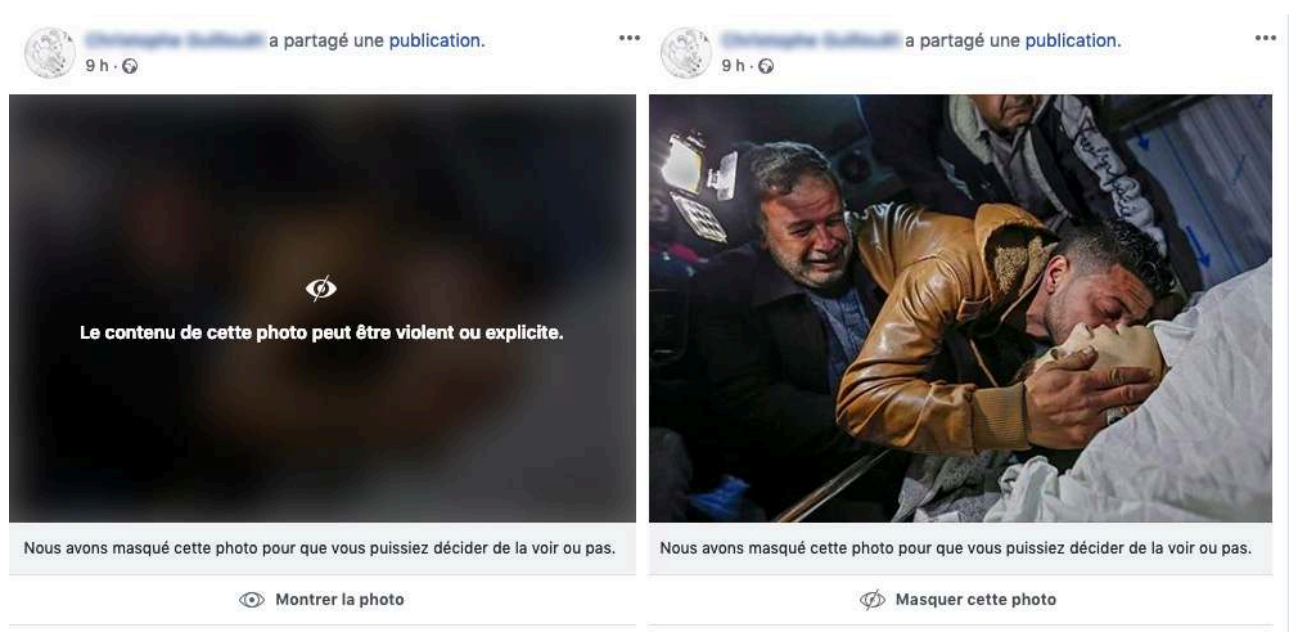

Fig. 8 Warning screen for violent images on Facebook (screenshot).

The use of images has its limits. While they are an effective means to bear witness to brief and spectacular incidents, they are of little value in reporting slower and more opaque processes. Ahead of the gilets jaunes demonstrations, for example, the police carried out thousands of preventive arrests in a restriction of the right to protest every bit as worrying as physical intimidation ${ }^{38}$-but these actions have never been denounced with audiovisual evidence. Using images of violence has emerged as a means to grab the public's attention, but also to create easily understood storylines that pit the good guys against the bad guys in a pre-established narrative legitimized by the alert function.

Often analyzed through a media prism, online communication presents us with opportunistic behavior and emerging uses shaped by circumstance. The alert process and the viral phenomenon that powers it are prime examples of emerging practices. The alert was raised over police violence in France under specific conditions. The enigma presented by the gilets jaunes and their unprecedented social movement attracted widespread public attention. In this context, the inability of the mainstream media to relay what was happening on the ground and the disconnect with direct communication available on social media prompted part of the public to change its information-gathering behavior. Outside of any analytical framework, the proliferation of audiovisual testimonies of police violence has created a process with its own rules of validation and dissemination, driven by the ongoing confrontation over the crisis.

While the emergence of this social narrative is the result of exceptional circumstances it is not due to chance. Behind the management of the gilets jaunes crisis an historical evolution is playing out in social democracy, which, in the face of growing political impotence, is giving up ground little by little to the temptations offered by authoritarianism. ${ }^{39}$ Is it nevertheless possible to speak of subalterns making their voices heard? The narrative dynamics of the exposure of violence have in reality nourished a counter-narrative distinct from the demands of the gilets jaunes, which, on account of its moral legitimacy, has gradually taken hold in public debate. 


\section{BIBLIOGRAPHY}

All digital sources were verified on December 15, 2020.

Bertho, Alain. "Enoncés visuels des mobilisations. Autoportraits des peuples," Anthropologie et Sociétés 40/1 (2016): 31-50.

Boltanski, Luc. La Souffrance à distance : Morale humanitaire, médias et politique. Paris: Gallimard, 1993.

Bolter, Jay David and Richard Grusin. Remediation. Understanding New Media. Cambridge Ma: The MIT Press, 1999.

Bourgatte, Michaël. Voir le sang des bêtes? Des images contre l'industrie de l'élevage et de l'abattage. Paris: MKF éd., 2021.

Bouté, Edouard and Clément Mabi. "Des images en débat: de la blessure de Geneviève Legay à la répression des Gilets Jaunes," Études de communication. Langage, information, médiations 54/1 (2020): 29-52. https://journals.openedition.org/edc/9996.

Cardon, Dominique. "Fake News Panic: Les nouveaux circuits de l'information." In Culture numérique. Paris: Presses de Sciences Po, 2019, 261-276.

Crouch, Colin. Post-démocratie (2005), translated by Yves Coleman. Paris: Diaphanes, 2013.

Chateauraynaud, Francis. Alertes et lanceurs d'alerte. Paris: Que sais-je ?/Humensis, 2020.

Fillieule, Olivier and Fabien Jobard. Politiques du désordre. La police des manifestations en France. Paris : Ed. Le Seuil, 2020.

Fraser, Nancy. "Rethinking the Public Sphere: A Contribution to the Critique of Actually Existing Democracy," Social Text 25/26 (1990): 56-80.

Godin, Romaric. La Guerre sociale en France: Aux sources économiques de la démocratie autoritaire. Paris: La Découverte, 2019.

Gunthert, André. "L'image virale comme preuve: Les vidéos des violences policières dans la crise des Gilets jaunes," Communications 106, (June 2020): 187-207. https://www.cairn.info/revuecommunications-2020-1-page-187.htm

Ingram, Marielle. "Contracirculation: On Rewriting the Terms of Engagement with Images of Black Suffering," Real Life, June 29, 2020. https://reallifemag.com/contracirculation/

Mann, Steve; Nolan, Jason and Barry Wellman. "Sousveillance: Inventing and Using Wearable Computing Devices for Data Collection in Surveillance Environments," Surveillance \& Society 1/3, (2003): 331-355.

Meyer, Michaël. “Copwatching et perception publique de la police: L'intervention policière comme performance sous surveillance," Ethnographiques.org 21 (November 2010). http:// www.ethnographiques.org/2010/Meyer

Michaud, Yves. "Critique de la crédulité," Etudes photographiques 12, (November 2002): 110-125. https://journals.openedition.org/etudesphotographiques/321

Spivak, Gayatri Chakravorty. Les Subalternes peuvent-elles parler? (1988), Trad. Jérôme Vidal. Paris: Amsterdam, 2009. 
Sontag Susan. Devant la douleur des autres (translated from English by F. Durand-Bogaert. Paris: C. Bourgois, 2003.

Sources

Amnesty International. "Arrêté·e·s pour avoir manifesté: La loi comme arme de répression des manifestante.s pacifiques en France.” Report, September 28, 2020. https://www.amnesty.org/fr/ documents/eur21/1791/2020/fr/

Buisine, Rémy. "Une femme en blouse blanche, tirée par les cheveux...," Twitter (video, 2 min. 14), June 16, 2020. https://twitter.com/RemyBuisine/status/1272935058630983681

BVA. "Les Français et la police," poll, June 17, 2016. https://www.bva-group.com/sondages/lesfrancais-et-la-police/

Collectif Sociétés de journalistes. "L'article 24 de la future loi 'sécurité globale' menace la liberté d'informer," Le Monde, November 10, 2020. https://www.lemonde.fr/idees/article/2020/11/10/ l-article-24-de-la-future-loi-securite-globale-menace-la-liberte-d-informer-alertent-des-societesde-journalistes_6059188_3232.html

Commissaires de police - SICP. “Nous rétablissons la vérité par une vidéo de @BFMTV," Twitter (video, 26 sec.), June 16, 2020. https://twitter.com/SICPCommissaire/status/

1272974732879491073

Dufresne, David. “Allo @Place_Beauvau-c'est pour un signalement,” Twitter, December 4, 2018. https://twitter.com/davduf/status/1070065199275798529

Dufresne, David. Un pays qui se tient sage (film, 86 min.), Le Bureau/Jour2fête, 2020.

Fauvergue, Jean-Michel and Alice Thourot. "Rapport fait au nom de la commission des lois constitutionnelles, de la législation et de l'administration générale de la République, sur la proposition de loi, après engagement de la procédure accélérée, relative à la sécurité globale," Assemblée nationale, rapport 3527, November 5, 2020. http://www.assemblee-nationale.fr/dyn/ 15/rapports/cion_lois/115b3527_rapport-fond\#

France 2, journal télévisé de $20 \mathrm{~h}$, interview of prime minister Edouard Philippe by Laurent Delahousse (17 min. 44), January 12, 2020. https://www.francetvinfo.fr/economie/retraite/ reforme-des-retraites/reforme-des-retraites-nous-irons-au-bout-de-cette-reforme-affirmeedouard-philippe_3781909.html

G[uibert], Antoine. "Interpellation particulièrement violente”, Twitter (photos), June 16, 2020. https://twitter.com/AntoineGuibert4/status/1272941085287989251

Ly, Ladj. Les Misérables (film, 103 min.). SRAB Films, 2019.

Mellaz, Imen. “Cette femme, c'est ma mère,” Twitter, June 16, 2020. https://twitter.com/ Mellazimen/status/1272929930611953666

Menand Elise and Benoît Sauvage. "Violences policières: quelle justice?” Envoyé spécial, France 2, June 11, 2020. https://www.france.tv/france-2/envoye-special/1544605-violences-policieresquelle-justice.html (withdrawn, 2021).

Mouraud, Jacline. “Coup de gueule”, Youtube (video, 4 min. 38), October 27, 2018. https:// www.youtube.com/watch?v=06pOTxTvnBU

Odoxa. "Le mouvement de grève contre la réforme des retraites et les violences policières," poll, January 23, 2020. http://www.odoxa.fr/sondage/francais-demandent-fin-de-greve-condamnentactions-ciblees-sympathisants-de-gauche-rn-eux-se-radicalisent/ 
Price, Melanye. "Put Limits on the Violent Videos (Please Stop Showing the Video of George Floyd's Death)," New York Times, June 4, 2020, 27. https://www.nytimes.com/2020/06/03/ opinion/george-floyd-video-social-media.amp.html

Schneidermann, Daniel. “Soignants: live contre live," Arrêt sur images, June 17, 2020. https:// www.arretsurimages.net/chroniques/le-matinaute/soignants-live-contre-live

Surveillons-les ! Comité de liaison contre les violences policières de Lyon. La Fabrique de l'oubli. Deux ans de plaintes contre la police en manifestation à Lyon, report, November 17, 2020. https://surveillonslesart.files.wordpress.com/202

Vidooshan. "Une infirmière vient de se faire interpellé [sic] violemment," Twitter (video, protected tweet), June 16, 2020. https://twitter.com/vidooshan/status/1272906479910215680

Wargon, Emmanuelle. "Il n'y a aucun complot du gouvernement contre la voiture!," Twitter (video, 2 min. 15), November 4, 2018. https://twitter.com/EmmWargon/status/

1059137494636265475

\section{NOTES}

1. Alain Bertho, "Enoncés visuels des mobilisations. Autoportraits des peuples," Anthropologie et Sociétés 40/1 (2016): 31-50.

2. David Dufresne, The Monopoly of Violence (film, 86 min.), Le Bureau/Jour2fête, 2020.

3. Gayatri Chakravorty Spivak, Les Subalternes peuvent-elles parler? (1988), translated from English by Jérôme Vidal (Paris: Amsterdam, 2009).

4. Nancy Fraser, "Rethinking the Public Sphere: A Contribution to the Critique of Actually Existing Democracy," Social Text 25/26 (1990), 56-80.

5. Bertho, "Enoncés visuels des mobilisations. Autoportraits des peuples".

6. Ladj Ly, Les Misérables (film, 103 min.), SRAB Films, 2019.

7. Steve Mann, Jason Nolan and Barry Wellman, "Sousveillance: Inventing and Using Wearable Computing Devices for Data Collection in Surveillance Environments," Surveillance \& Society 1/3, (2003): 331-355.

8. Michaël Meyer, "Copwatching et perception publique de la police: L'intervention policière comme performance sous surveillance," Ethnographiques.org 21 (November 2010). http:// www.ethnographiques.org/2010/Meyer

9. Surveillons-les ! Comité de liaison contre les violences policières de Lyon, La Fabrique de l'oubli. Deux ans de plaintes contre la police en manifestation à Lyon, report, November 17, 2020. https:// surveillonslesart.files.wordpress.com/202

10. Elise Menand and Benoît Sauvage, "Violences policières: quelle justice?" Envoyé spécial, France 2, June 11, 2020. https://www.france.tv/france-2/envoye-special/1544605-violencespolicieres-quelle-justice.html (withdrawn, 2021).

11. Francis Chateauraynaud, Alertes et lanceurs d'alerte (Paris: Que sais-je?/Humensis, 2020).

12. Jacline Mouraud, "Coup de gueule", Youtube (video, 4 min. 38), October 27, 2018. https:// www.youtube.com/watch?v=06pOTxTvnBU. The video response from Emmanuelle Wargon, State Secretary at the Ministry of Ecology, on November 4, 2018, was proof that the message reached its intended recipient (Emmanuelle Wargon. "Il n'y a aucun complot du gouvernement contre la voiture!," Twitter (video, 2 min. 15), November 4, 2018. https://twitter.com/EmmWargon/ status/1059137494636265475).

13. David Dufresne, “Allo @Place_Beauvau-c'est pour un signalement," Twitter, December 4, 2018. https://twitter.com/davduf/status/1070065199275798529. The series totaled 707 reports as of June 2019. 
14. Dominique Cardon, "Fake News Panic: Les nouveaux circuits de l'information," Culture numérique, (Paris: Presses de Sciences Po, 2019), 261-276.

15. "Rarely do users take action beyond the click of a button. Such users drain these images of their value" (Marielle Ingram. "Contracirculation: On Rewriting the Terms of Engagement with Images of Black Suffering," Real Life, June 29, 2020. https://reallifemag.com/contracirculation/).

16. Jay David Bolter and Richard Grusin, Remediation. Understanding New Media (Cambridge Ma: The MIT Press, 1999).

17. Melanye Price, "Put Limits on the Violent Videos (Please Stop Showing the Video of George Floyd's Death)," New York Times, June 4, 2020, 27. https://www.nytimes.com/2020/06/03/ opinion/george-floyd-video-social-media.amp.html

18. Susan Sontag, Devant la douleur des autres (translated from English by F. Durand-Bogaert (Paris: C. Bourgois, 2003).

19. Yves Michaud, “Critique de la crédulité," Etudes photographiques 12 (November 2002), 110-125. https://journals.openedition.org/etudesphotographiques/321

20. Michaël Bourgatte, Voir le sang des bêtes? Des images contre l'industrie de l'élevage et de l'abattage (Paris: MKF éd., 2021).

21. France 2, journal télévisé de $20 \mathrm{~h}$, entretien d'Edouard Philippe avec Laurent Delahousse (17 min. 44), January 12, 2020. https://www.francetvinfo.fr/economie/retraite/reforme-desretraites/reforme-des-retraites-nous-irons-au-bout-de-cette-reforme-affirme-edouard-

philippe_3781909.html

22. Odoxa, "Le mouvement de grève contre la réforme des retraites et les violences policières," poll, January 23, 2020. http://www.odoxa.fr/sondage/francais-demandent-fin-de-grevecondamnent-actions-ciblees-sympathisants-de-gauche-rn-eux-se-radicalisent/

23. Dufresne, The Monopoly of Violence.

24. Edouard Bouté and Clément Mabi, "Des images en débat: de la blessure de Geneviève Legay à la répression des Gilets Jaunes," Études de communication. Langage, information, médiations 54/1 (2020): 29-52. https://journals.openedition.org/edc/9996.

25. Vidooshan, "Une infirmière vient de se faire interpellé [sic] violemment," Twitter (video, protected tweet), June 16, 2020. https://twitter.com/vidooshan/status/1272906479910215680

26. Imen Mellaz, "Cette femme, c'est ma mère," Twitter, June 16, 2020. https://twitter.com/ Mellazimen/status/1272929930611953666

27. Rémy Buisine, "Une femme en blouse blanche, tirée par les cheveux...," Twitter (video, 2 min. 14), June 16, 2020. https://twitter.com/RemyBuisine/status/1272935058630983681

28. Antoine G[uibert], “Interpellation particulièrement violente”, Twitter (photos), June 16, 2020. https://twitter.com/AntoineGuibert4/status/1272941085287989251

29. Daniel Schneidermann, "Soignants: live contre live," Arrêt sur images, June 17, 2020. https:// www.arretsurimages.net/chroniques/le-matinaute/soignants-live-contre-live

30. Commissaires de police - SICP, "Nous rétablissons la vérité par une vidéo de @BFMTV," Twitter (video, 26 sec.), June 16, 2020. https://twitter.com/SICPCommissaire/status/ 1272974732879491073

31. Luc Boltanski, La Souffrance à distance: Morale humanitaire, médias et politique (Paris: Gallimard, 1993).

32. BVA, "Les Français et la police," poll, June 17, 2016. https://www.bva-group.com/sondages/ les-francais-et-la-police/

33. André Gunthert, "L'image virale comme preuve: Les vidéos des violences policières dans la crise des Gilets jaunes," Communications 106, (June 2020) 187-207. https://www.cairn.info/revuecommunications-2020-1-page-187.htm

34. Chateauraynaud, Alertes et lanceurs d'alerte.

35. Olivier Fillieule and Fabien Jobard, Politiques du désordre. La police des manifestations en France (Paris : Ed. Le Seuil, 2020). 
36. Collectif Sociétés de journalistes, "L'article 24 de la future loi 'sécurité globale' menace la liberté d'informer," Le Monde, November 10, 2020. https://www.lemonde.fr/idees/article/ 2020/11/10/l-article-24-de-la-future-loi-securite-globale-menace-la-liberte-d-informer-alertentdes-societes-de-journalistes_6059188_3232.html

37. Jean-Michel Fauvergue and Alice Thourot, "Rapport fait au nom de la commission des lois constitutionnelles, de la législation et de l'administration générale de la République, sur la proposition de loi, après engagement de la procédure accélérée, relative à la sécurité globale," Assemblée nationale, rapport 3527, November 5, 2020. http://www.assemblee-nationale.fr/dyn/ 15/rapports/cion_lois/115b3527_rapport-fond\#

38. Amnesty International, "Arrêté·e's pour avoir manifesté: La loi comme arme de répression des manifestant·ess pacifiques en France." Report, September 28, 2020. https://www.amnesty.org/fr/ documents/eur21/1791/2020/fr/

39. Colin Crouch, Post-démocratie, translated by Yves Coleman (Paris: Diaphanes, 2013); Romaric Godin, La Guerre sociale en France: Aux sources économiques de la démocratie autoritaire (Paris: La Découverte, 2019).

\section{ABSTRACTS}

With the gilets jaunes (yellow vests) crisis the debate about police violence emerges as a major example of a counter-narrative, mainly relying on the online circulation of viral images. This article analyses the conditions for the emergence in public debate of a minority narrative thanks to digital media. Apart from activist communication, faced with powerful denial mechanisms, an autonomous alert process has been established based on the credibility of the documentary format, the argumentative dynamic of the online conversation, and the mobilization of an aesthetic of pity.

\section{INDEX}

Keywords: visual culture, media, video, social media, alert

\section{AUTHORS}

\section{ANDRÉ GUNTHERT}

André Gunthert is Associate Professor in visual history at EHESS (Paris) and the founder of the journal Études photographiques (1996-2017). His research has looked into the beginnings of photography, the revolution of instantaneous photography, illustrated publishing, photojournalism, documentary cinema and comics. As an observer of the transition to a digital world, he has described the new ways in which images are shared and their conversational uses (L'Image partagée, Textuel, 2015). His recent work focuses on the social uses of images, the history of informational images, and the theory of visual narrative.

EHESS, Cral-Cehta 